\title{
Distribution of minor metallic elements within waste incineration bottom ashes defined by WDX/EDX spectrometry
}

\author{
Piotr R. Kowalski, Monika Kasina, and Marek Michalik \\ Institute of Geological Sciences, Jagiellonian University, Gronostajowa 3a, 30-387 Kraków, Poland \\ Correspondence: Piotr R. Kowalski (p.kowalski@doctoral.uj.edu.pl)
}

Received: 31 May 2018 - Revised: 30 July 2018 - Accepted: 5 August 2018 - Published: 5 September 2018

\begin{abstract}
A number of metallic elements are inherited from waste during thermal treatment and concentrated in the incineration residues. Because the major part of the incineration residue mass are bottom ashes (BAs), their study is of great importance from the point of view of their environmental impact or resource potential. The general focus of this study was on the minor metallic elements present in BAs. They co-occurred with main phases and often determined the inherited potential of the material. The analysed residues were produced from municipal and industrial waste. The BAs were studied using spectroscopic methods of chemical microanalysis: energy dispersive X-ray spectrometry (EDX) and wavelength dispersive X-ray spectrometry (WDX). Both the main and minor metallic elements were concentrated in metallic components. They were typically present as separate grains and metallic inclusions (commonly in the glass matrix of the grains) ranging in size from several to hundreds of micrometres. Despite Fe-, Al- and Cu-rich occurrences, metallic elements rarely occurred in fragments composed of a single element. Their main forms of occurrence were alloy grains, admixtures in polymetallic occurrences and micro-inclusions in glassy matrix. The content of particular elements in those forms was investigated and described in greater detail. Even though two types of bottom ash were formed from different types of waste and differences in used technologies were present, the obtained materials contained metallic components having similar attributes. Elevated concentrations of not only $\mathrm{Fe}$ and $\mathrm{Al}$, but also $\mathrm{Ti}, \mathrm{Cu}$ and $\mathrm{Zn}$, allow us to consider bottom ash as a promising material from the point of view of metallic elements' recovery (e.g. by the physical concentration of elements through gravity or magnetic methods).
\end{abstract}

\section{Introduction}

Waste incineration is one of the most common treatment methods in waste management. It allows waste mass and volume reduction. Nevertheless, it causes growth in the worldwide production of waste incineration residues. During thermal treatment, waste is detoxified and transformed into three solid materials: bottom ash (BA), fly ash (FA) and air pollution control (APC) residues. As concentrates of inflammable waste fraction, they are composed of newly formed phases and components inherited from waste such as metallic fragments, fragmented glass or ceramic (Chandler et al., 1997). Elements inherited from waste are entrapped in incineration residues and excluded from their natural cycles; therefore, procedures for the post-treatment management or recycling of incineration residues need to be developed. Most metallic elements concentrate in BAs thus, they might be considered as a source of valuable components or waste-based raw material in industrial applications (Funari et al., 2015; Lam et al., 2010; Kowalski et al., 2016).

BAs are heterogeneous grainy materials. Their composition is mainly dependent on the local waste stream composition, applied waste management system and technology of incineration. Besides amorphous and crystalline components formed during incineration, BAs are rich in residual components inherited from waste (often barely affected by high temperature). Also, metallic components are present in the BAs, even if the recycling of metal products is performed prior to the thermal treatment (Chandler et al., 1997; Saffarzadeh et al., 2009; Wei et al., 2011). After thermal processing, the next stage of recycling in the incineration plant is usually performed by using single magnets or eddycurrent separators. The process is effective for the separation of large fragments of metal products released in the furnace from waste. Nevertheless, it is not possible to recover single 
or small metal fragments without fragmentation of the BA grains.

Common metallic elements such as $\mathrm{Fe}, \mathrm{Al}$ and $\mathrm{Mg}$ are present in the BAs in the highest amount, while up to a few wt $\%$ of other metallic elements is also often present (e.g. Ti, $\mathrm{Zn}, \mathrm{Cu}, \mathrm{Cr}$ ). Currently, it is considered that the recovery of single elements might not be economically reasonable because of the presence of easy accessible natural or secondary resources. Nevertheless, incineration residues could be treated as easily accessible, produced continuously in large amounts, and a waste-based source of at least a few metallic elements (Kuo et al., 2007). From this point of view, the value of elements also present in minority might be encouraging for developing procedures of their separation and recovery. For the estimation of BAs' resource potential, the basic studies of minor metallic elements are of great importance. Based on this presumption, the main focus of this study was on BAs' minor metallic elements, especially those present as side elements in alloys and dispersed within various BA phases. We also focus on the distribution of minor metallic elements within the phases in two types of BA produced from waste generated in households and industry.

\section{Materials \& analytical methods}

\subsection{Bottom ashes sampling and used incineration technologies}

To investigate minor metallic components in waste incineration BAs, $285 \mathrm{~kg}$ of the material in total was collected from two operating plants located in Poland during several sampling campaigns (in the years from 2015 to 2018).

Twelve samples of BA were collected from a municipal solid waste incineration (MSWI) plant $(155 \mathrm{~kg})$. Each sample represented an averaged portion of fresh material and was collected from a depth of $30 \mathrm{~cm}$ on an uncovered heap. According to the European List of Waste (EPA, 2002), this type of BA (waste code: 190112 ) is categorised as "bottom ash and slag other than those mentioned in $190111^{*}$ (* bottom ash and slag containing dangerous substances)". The plant is now under reconstruction (planned efficiency of waste incineration will be $300000 \mathrm{t} \mathrm{yr}^{-1}$ ), but at the time when the samples were collected it was incinerating up to $55000 \mathrm{t}$ of waste every year. The plant was equipped with a shaft furnace, where waste $\left(<8 \mathrm{th}^{-1}\right)$ was thermally treated for 30-120 min at temperatures ranging from 950 to $1100^{\circ} \mathrm{C}$. Hot BA was cooled with water and stored on an uncovered heap. Through a technological process, products composed of ferrous metals were separated from the BA manually and by using magnetic separators. Flue gases from the furnace were led to an APC system where in a few steps the ashes and residues were separated, heat was recovered and gases were treated to neutralise its toxic and hazardous components $\left(\mathrm{NO}_{x}, \mathrm{SO}_{x}, \mathrm{HCl}, \mathrm{HF}\right.$, toxic metallic elements, dioxins, furans and organic pollutants) (Malczewski and Nadulski, 2010). In this plant BA, APC and FA were produced in the proportions of $91.5 \%, 7 \%$ and $1.5 \%$, respectively (Kowalski et al., 2017).

The second group of BA samples was collected in an industrial and hazardous waste incineration (IHWI) plant. This BA is categorised as "bottom ash and slag containing dangerous substances" (waste code: $190111 *$ ). Because of strict safety regulations, the samples were prepared by incineration plant employees. Seven samples of fresh BA were collected at the end of the technological line $(130 \mathrm{~kg})$. The BA was produced in the incineration plant, where $\sim 800$ categories of waste (including 379 hazardous types) are thermally treated. The plant is equipped with a rotary furnace, which is able to incinerate up to $50000 \mathrm{t}$ of waste per year. The incineration time was 25-60 min and the temperatures ranged from 900 to $1150^{\circ} \mathrm{C}$. After incineration the BA is cooled with water, and during transportation to storing containers, fragments of ferrous metal products are separated using magnetic separators. The installation is equipped with an advanced multi-stage APC system to recover energy and deal with elevated content of toxic and hazardous components of flue gases. This is a combination of washers, dryers, filters and absorbers, used for effective removal of $\mathrm{Hg}, \mathrm{HCl}, \mathrm{SO}_{x}, \mathrm{NO}_{x}, \mathrm{HF}$, dioxins, furans, PCBs and toxic metallic elements (Pikoń and Grabski, 2006). In this plant, BA and APC are produced in weight at the proportion of $70: 30$.

Additionally to the BA samples, four samples of FA ( $40 \mathrm{~kg})$ and eight samples of APC residues $(\sim 40 \mathrm{~kg})$ were collected and analysed in parallel.

\subsection{Sample preparation}

Prior to analysis, BA samples from both incineration plants were dried and averaged using Retsch sample splitters. After the removal of fragments of metal products that could not be crushed or milled ( $<5 \mathrm{wt} \%$ of the MSWI BA and $1-2 \mathrm{wt} \%$ of the IHWI BA samples), the BAs were crushed using a jaw crusher (tungsten carbide crushing elements). For chemical analysis, the BAs were milled in a Retsch planetary ball mill for $20 \mathrm{~min}(2 \times 10 \mathrm{~min}, 250 \mathrm{rpm}$, tungsten carbide grinding elements). For quantitative $\mathrm{X}$-ray diffraction, the samples were crushed to $0.4 \mathrm{~mm}$ and milled in a McCrone micronising mill (in alcohol, $10 \mathrm{~min}$, samples analysed as disoriented specimen).

\subsection{Analytical methods}

In both types of BA, the content of residual components was determined. From $1 \mathrm{~kg}$ of each sample, fragmented metal products and other heat-resistant components were manually separated and weighed. In the MSWI BA, they were primarily represented by fragmented glass and ceramic products.

The BAs' chemical composition was determined by $\mathrm{Bu}-$ reau Veritas Upstream Minerals (formerly AcmeLabs An- 
Table 1. Averaged content of major elements in BAs from waste incineration.

\begin{tabular}{lllllllllll}
\hline element (wt \%) & $\mathrm{Si}$ & $\mathrm{Ca}$ & $\mathrm{Fe}$ & $\mathrm{Na}$ & $\mathrm{Al}$ & $\mathrm{Mg}$ & $\mathrm{Ti}$ & $\mathrm{C}_{\text {tot }}$ & $\mathrm{S}_{\text {tot }}$ & LOI \\
\hline MSWI BA $^{\mathrm{a}}$ & 24.98 & 11.72 & 6.80 & 4.97 & 4.00 & 1.00 & 0.45 & 0.40 & 0.33 & 1.22 \\
$\mathrm{SD}$ & 1.7 & 0.7 & 2.4 & 0.6 & 0.7 & 0.1 & 0.1 & 0.2 & 0.1 & 1.7 \\
\hline IHWI BA $^{\mathrm{b}}$ & 14.51 & 8.37 & 6.73 & 6.22 & 5.32 & 1.06 & 3.01 & 10.42 & 1.73 & 14.7 \\
$\mathrm{SD}$ & 1.6 & 2.1 & 2.2 & 1.2 & 0.9 & 0.2 & 1.1 & 4.9 & 0.3 & 6.6 \\
\hline
\end{tabular}

${ }^{a}$ Averaged values based on analysis of 9 samples. ${ }^{b}$ Averaged values based on analysis of 7 samples. SD - standard deviation.

Table 2. Averaged content of minor elements in BAs from waste incineration.

\begin{tabular}{lllllllllllll}
\hline element (wt \%) & $\mathrm{K}$ & $\mathrm{P}$ & $\mathrm{Cu}$ & $\mathrm{Zn}$ & $\mathrm{Mn}$ & $\mathrm{Cr}$ & $\mathrm{Pb}$ & $\mathrm{Zr}$ & $\mathrm{Sn}$ & $\mathrm{Ni}$ & $\mathrm{Co}$ & $\sum$ REE \\
\hline MSWI BA $^{\mathrm{a}}$ & 6656 & 3422 & 1290 & $1229^{\mathrm{c}}$ & 645 & 552 & $277^{\mathrm{d}}$ & 208 & 174 & 56 & 43 & 88 \\
SD & 570 & 616 & 567 & 985 & 126 & 278 & 355 & 37 & 107 & 19 & 12 & 12 \\
\hline IHWI BA $^{\mathrm{b}}$ & 5088 & 6072 & 3635 & $6433^{\mathrm{e}}$ & 1582 & 1534 & $486^{\mathrm{f}}$ & 696 & 561 & 806 & 240 & 262 \\
SD & 947 & 2145 & 1561 & 4436 & 689 & 516 & 496 & 258 & 480 & 295 & 109 & 137 \\
\hline
\end{tabular}

a Averaged values based on analysis of 9 samples. ${ }^{\mathrm{b}}$ Averaged values based on analysis of 7 samples. ${ }^{\mathrm{c}}$ In 1 sample: $0.39 \mathrm{wt} \% \mathrm{Zn}$; ${ }^{\mathrm{d}}$ in $1 \mathrm{sample:} 0.13 \mathrm{wt} \%$ Pb; ${ }^{\mathrm{e}}$ in 3 samples: $0.9-1.2 \mathrm{wt} \% \mathrm{Zn} ;{ }^{\mathrm{f}}$ in 2 samples: $\sim 0.12 \mathrm{wt} \% \mathrm{~Pb}$. SD - standard deviation.

alytical Laboratories Ltd.) in Vancouver, Canada. The elements' content was measured by inductively coupled plasma optical emission and mass spectrometry (ICP-OES and ICPMS, respectively). The total content of $\mathrm{C}$ and $\mathrm{S}$ were also measured using a LECO combustion analysis and loss on ignition (LOI) was estimated based on the thermal method.

The BAs' mineral composition was determined using Xray powder diffraction. Measurements were performed in the angle range of $2-70^{\circ} 2 \Theta$ using a Philips X'Pert APD diffractometer (goniometer PW3020, curved graphite crystal monochromator, $\mathrm{CuK} \alpha$ radiation) with a step of $0.02^{\circ}$ per $5 \mathrm{~s}$ for quantitative analyses. Interpretations were made based on the database of the Mineralogical Society of America (Downs and Hall-Wallace, 2003) and SEIFERT AutoQuan software was used for the quantitative calculations (based on the Rietveld refinement method and the addition of internal standard: $10 \mathrm{wt} \%$ of $\mathrm{ZnO}$.

Analyses of BAs in polished thin sections and micro-spot analyses were performed using a Hitachi S-4700 field emission scanning electron microscope (FE-SEM; operating voltage of $20 \mathrm{kV}$, time for standardless microanalysis $100 \mathrm{~s}$, specimen coated with carbon) equipped with a Thermo Noran energy dispersive X-ray spectrometry (EDX) analyser (several hundred EDX analyses of metallic components were made) and a JEOL Superprobe JXA-8230 electron microprobe equipped with 5 wavelength dispersive X-ray spectrometry (WDX) detectors (calibration with standards, beam size $10 \mu \mathrm{m}$, accelerating voltage $20 \mathrm{kV}, 19$ elements measured including direct measurement of $\mathrm{O}$, specimen coated with carbon). Six samples were analysed using the microprobe. From each material, $\sim 300$ spot analyses were made (most of them were focused on metallic components). The size distribution of metallic components was determined by measuring their sizes in two dimensions using SEM images.

\section{Results and discussion}

The BAs were materials rich in $\mathrm{Si}, \mathrm{Ca}, \mathrm{Fe}, \mathrm{Na}$ and $\mathrm{Al}$. In lower amounts, $\mathrm{Mg}$, Ti, $\mathrm{C}$ and $\mathrm{S}$ were present (Table 1). In comparison to the MSWI BA, the IHWI BA had less Si and $\mathrm{Ca}$, similar content of $\mathrm{Fe}, \mathrm{Mg}$ and usually slightly higher content of other main elements. In both types of BAs, the content of particular elements varied in some range when comparing single samples collected in different sampling campaigns (standard deviation values for the analysed group of samples are given for each value in Tables 1 and 2). The IHWI BA chemical composition was less uniform, which could be expected due to the fact that the output waste mixture was much more diversified than the MSWI BA. Additionally, Chandler et al. (1997) reported the variability of BA chemical composition mostly as a result of changes in the incinerated waste composition, but also as a result of the effectiveness of the waste management system and the used techniques of waste pre-treatment and BA valorisation in the incineration plant. In contrast to the variability of chemical composition, BA from the industrial waste was macroscopically more homogeneous and contained smaller amounts of residual components (only $0.5 \mathrm{wt} \%-2.0 \mathrm{wt} \%$ of metallic fragments). The MSWI BA contained $25 \mathrm{wt} \%-35 \mathrm{wt} \%$ of fragmented glass, $2.5 \mathrm{wt} \%-5.5 \mathrm{wt} \%$ of metal and $2.0 \mathrm{wt} \%-$ $7.0 \mathrm{wt} \%$ of ceramic products.

The chemical composition of the BAs was reflected in their phase composition. Both types of BA contained a high amount of amorphous phase, mostly represented by sili- 

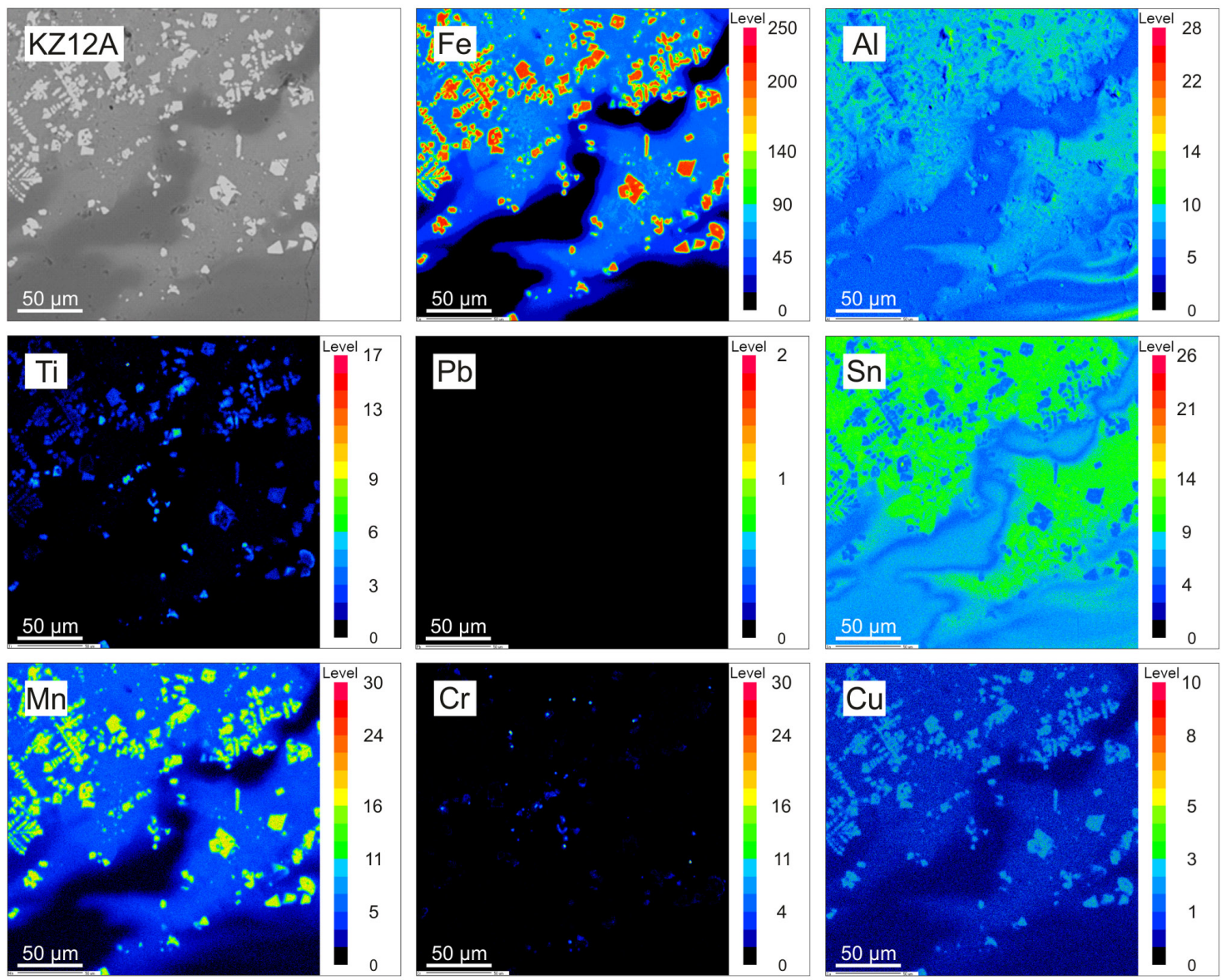

Figure 1. MSWI BA WDX maps. Glassy matrix of the BA grain rich in metallic inclusions (mostly Fe-Mn-rich inclusions).

cate glass, although its content was higher in the IHWI BA (55 wt \%-65 wt \% in MSWI BA vs. $65 \mathrm{wt} \%-80 \mathrm{wt} \%$ in IHWI BA) (Kowalski et al., 2017). Crystalline phase was composed of several phases in both types of BA. The main minerals were silicates and aluminosilicates containing $\mathrm{Ca}$ and alkalis, carbonates and oxides. In smaller amounts phosphates, sulphates and chlorides were present. The MSWI BA contained more quartz $\left(\mathrm{SiO}_{2}\right)$, and melilite group minerals $\left(\mathrm{Ca}_{2} \mathrm{Mg}\left[\mathrm{Si}_{2} \mathrm{O}_{7}\right]-\mathrm{Ca}_{2} \mathrm{Al}\left[\mathrm{AlSiO}_{7}\right]\right)$, whereas the IHWI BA was rich in sulphate minerals $\left(\mathrm{Ca}\left[\mathrm{SO}_{4}\right]\right.$. $\left.\mathrm{nH}_{2} \mathrm{O} ; \mathrm{Na}_{2} \mathrm{Ca}\left[\mathrm{SO}_{4}\right]_{2} ; \mathrm{Na}_{2}\left[\mathrm{SO}_{4}\right]\right)$, calcite $\left(\mathrm{Ca}\left[\mathrm{CO}_{3}\right]\right)$ and $\mathrm{Fe}-$ oxides $\left(\mathrm{Fe}_{x} \mathrm{O}_{y}\right)$.

In both types of BA, the group of minor elements was dominated by metallic elements. Ti, $\mathrm{Cu}, \mathrm{Zn}, \mathrm{Mn}$ and $\mathrm{Cr}$ were the most important (Table 2). Kuo et al. (2007) concluded that $\mathrm{Cu}, \mathrm{Zn}, \mathrm{Cr}$ and $\mathrm{Pb}$ from the group of minor metallic elements were concentrated mostly in the BA and are promising from the point of view of their recovery. Similar to the major elements, the content of minor components was diversified, which made the estimation of averaged values difficult, and for the average data to be reliable it was necessary to analyse a significant amount of the material. In general, the IHWI BA had remarkably higher content of minor metallic elements, and despite the level of variability this material seems to be more promising from the point of view of the metallic elements' recovery. Also in this material, in some samples a much higher content of particular elements was detected (e.g. in IHWI BA $>1 \mathrm{wt} \%$ of $\mathrm{Zn}$ ) (Table 2).

If considering the total content of metallic elements (Al, $\mathrm{Fe}, \mathrm{Mg}, \mathrm{Ti}, \mathrm{Mn}, \mathrm{Cr}, \mathrm{Ni}, \mathrm{Mo}, \mathrm{Cu}, \mathrm{Pb}, \mathrm{Zn}$ and $\mathrm{Sn}$ ), they constituted $>12.7 \mathrm{wt} \%(8.8 \mathrm{wt} \%-17.1 \mathrm{wt} \%)$ of the MSWI BA and $\sim 17.6 \mathrm{wt} \%(11.5 \mathrm{wt} \%-23.1 \mathrm{wt} \%)$ of the IHWI BA. In both materials, $2 / 3-4 / 5$ of the given amounts were Fe and Al. Metallic elements in both BA types were mostly concentrated in the form of metallic fragments, mainly as metallic inclusions (in the size of $1-15 \mu \mathrm{m}$ ) and separated metallic grains (in the size of 50-300 $\mu \mathrm{m}$ ). Those occurrences were dominated by $\mathrm{Fe}$ - and $\mathrm{Al}$-rich fragments, whereas others $(\mathrm{Cu}, \mathrm{Zn}, \mathrm{Ni}$ and very few $\mathrm{Pb}, \mathrm{Ti}, \mathrm{Cr}$, Sn-rich metallic fragments) were present less frequently. Similar forms and types of metallic occurrences were described by Wei et al. (2011). Also Funari et al. (2015) concluded that metallic elements are mostly concentrated in the fine-grained fraction of BAs and concentrations of some of them (e.g. $\mathrm{Cu}, \mathrm{Zn}, \mathrm{Pb}, \mathrm{Ni}$ ) are 

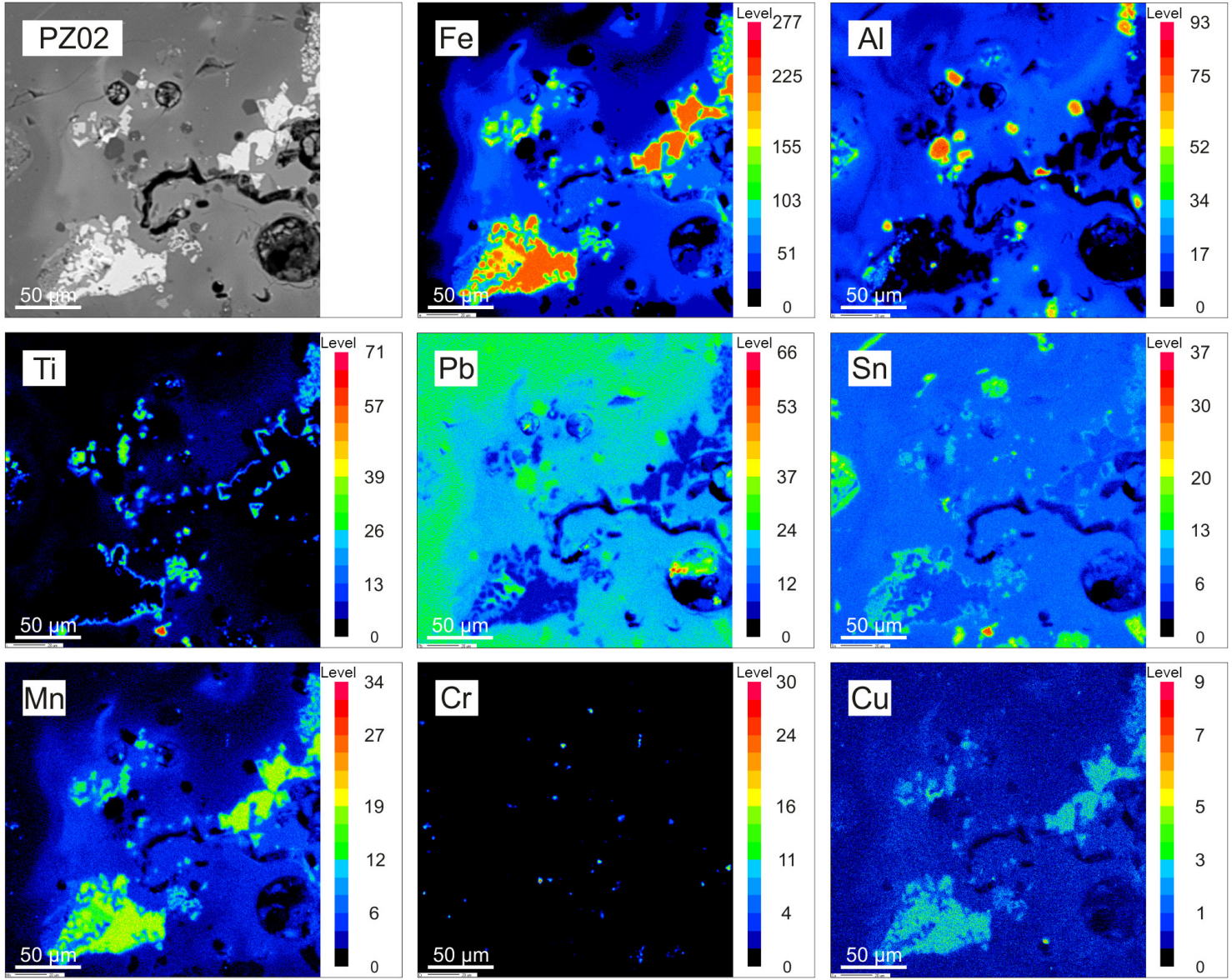

Figure 2. IHWI BA WDX maps. BA grain rich in metallic inclusions (Fe-Mn-Ti dominated).

close to values in low-grade ores. Most of the minor metallic elements in the BA were admixtures in multi-element metallic occurrences and other non-metallic phases. In the MSWI $\mathrm{BA}$ (based on WDX analysis), the usual content of $\mathrm{Pb}$ in the BA components was $<0.15 \mathrm{wt} \%$. Pb usually co-occurred with $\mathrm{Fe}, \mathrm{Sn}$ or $\mathrm{Zn}$ and was rarely present in the glass. From $25 \mathrm{wt} \%$ to $85 \mathrm{wt} \%$ of the $\mathrm{Pb}$ contained $\mathrm{Pb}$-rich occurrences and sulphides. $\mathrm{Cu}$ was mostly present in a form of metallic fragments containing $35 \mathrm{wt} \%-85 \mathrm{wt} \%$ of the element (also several wt $\%$ in sulphides). Rarely, $0.1 \mathrm{wt} \%-0.5 \mathrm{wt} \%$ of $\mathrm{Cu}$ was measured in the composition of $\mathrm{Fe}$ - and $\mathrm{Al}$-rich grains. From 0.1 to $0.5 \mathrm{wt} \%$ of $\mathrm{Mn} / \mathrm{Cr}$ were usually present in $\mathrm{Fe}-$ rich occurrences. Several percent of them were present in alloys with $\mathrm{Al}, \mathrm{Fe}$ and $\mathrm{Cr}(\mathrm{Mn})$ or $\mathrm{Fe}, \mathrm{Pb}$ and $\mathrm{Mn}(\mathrm{Cr})$. $\mathrm{Zn}$ was usually measured in Fe-rich grains in low amounts $(0.1 \mathrm{wt} \%-0.3 \mathrm{wt} \%)$, but $30 \mathrm{wt} \%-90 \mathrm{wt} \%$ was present in $\mathrm{Zn}$ rich occurrences and sulphides.

In the IHWI BA components (based on WDX analysis), $\mathrm{Cu}(0.2 \mathrm{wt} \%-4.0 \mathrm{wt} \%)$ was present mainly in multielement metallic occurrences. Higher content was detected in the composition of sulphides $(20 \mathrm{wt} \%-40 \mathrm{wt} \%)$ and $\mathrm{Cu}$-dominated fragments $(50 \mathrm{wt} \%-80 \mathrm{wt} \%)$. $\mathrm{Pb}(0.1 \mathrm{wt} \%-$
$0.3 \mathrm{wt} \%$ ) was present in $\mathrm{Fe}-$, $\mathrm{Al}-$ and $\mathrm{Sn}$-rich metallic fragments. In Pb-rich occurrences, its content reached $50 \mathrm{wt} \%$ $90 \mathrm{wt} \%$. Zn usually occured in multi-element occurrences and its content was in a range of $0.2 \mathrm{wt} \%-2.0 \mathrm{wt} \%$. Higher values of $\mathrm{Zn}(20 \mathrm{wt} \%-50 \mathrm{wt} \%)$ were present in sulphides and occurrences dominated by $\mathrm{Fe}$. $\mathrm{Cr}(0.1 \mathrm{wt} \%-1.0 \mathrm{wt} \%)$ was usually measured within $\mathrm{Fe}-$, Al- or Ti-rich fragments. Higher amounts of the element $(15 \mathrm{wt} \%-25 \mathrm{wt} \%)$ were present in multi-element occurrences. Mn was commonly present in various metallic fragments but its content was usually below $0.5 \mathrm{wt} \%$.

As presented in Figs. 1 and 2, microprobe WDX maps were generated in areas of glassy matrix containing grains rich in metallic inclusions. The results indicated that $\mathrm{Al}$ and Fe were concentrated mostly in discrete grains and large inclusions often containing several other elements in low amounts. $\mathrm{Mn}$ and $\mathrm{Cu}$ were present as minor components of metallic occurrences. Ti occurred in marginal zones of metallic Fe-rich fragments, $\mathrm{Cr}$ was concentrated in the form of micro-inclusions, while $\mathrm{Sn}$ and $\mathrm{Pb}$ were dispersed evenly with local spots of enrichment. This type of pattern was common among the glassy matrix of the BA grains where metal- 
lic inclusions were present. Areas of local enrichment in metallic elements were usually surrounding groups of metallic inclusions. As suggested by Saffarzadeh et al. (2009), metallic components could be fixed within the silica-rich matrix as a result of complex reactions in the furnace. This reaction seems to immobilise metals and make their recovery difficult, since silica is known to be a stabilising agent for heavy metals (Rodella et al., 2017). Minor metallic elements occurred in various types of BAs; they were present in similar forms and occurred as multi-element associations. Allegrini et al. (2014) estimated the recovery efficiency for Fe and nonferrous metals to be $85 \%$ and $61 \%$, respectively, which enables us to consider BA as an easily accessible and cheap waste-based source of important elements. Nevertheless, the recovery processes could be impeded because advanced recovery techniques need to be applied for dispersed elements or those entrapped within a number of phases (often as trace components), while the multiplicity of metallic fragments' chemical composition might be problematic, since a number of them contained a high amount of $\mathrm{Al}$ and $\mathrm{Fe}$.

\section{Conclusions}

Despite the differences in composition and type of waste they originate from, a number of similarities occurred during the analysis of both types of BA. They were composed of similar mineral phases, types of grains and had remarkably similar internal structures. Metallic elements represent $8.8 \mathrm{wt} \%-23.1 \mathrm{wt} \%$ of the BA (more metallic elements were concentrated in the IHWI BA). Besides high content of $\mathrm{Fe}$ and $\mathrm{Al}$ (ca. $10.8 \mathrm{wt} \%-12.1 \mathrm{wt} \%$ ), the elevated content of $\mathrm{Ti}$ $(\sim 3.0 \mathrm{wt} \%$ in the IHWI BA), $\mathrm{Cu}(0.1 \mathrm{wt} \%-0.4 \mathrm{wt} \%)$ and $\mathrm{Zn}(\sim 0.6 \mathrm{wt} \%$ in the IHWI BA) was measured. The BAs' chemical composition was diversified, but these variations did not affect the forms of metallic occurrences. Metallic elements were concentrated in both types of BA in the form of metallic inclusions (in the size of 1-15 $\mu \mathrm{m}$ ) and separate metallic grains (in the size of 50-300 $\mu \mathrm{m}$ ), mostly in the form of a few elements' occurrences. More metallic grains were present in the IHWI BA, despite the material being more diversified.

Minor metallic elements present in the BAs might be interesting from the point of view of their recovery. The most promising in terms of their recovery are occurrences dominated by a particular element, where its content is usually much higher than $50 \mathrm{wt} \%$, and when the metallic fragment is in the form of a separate grain or a component weakly bonded in the grains' aggregate.

Data availability. Jagiellonian University is the owner of the data, which can be released by the corresponding author on a reasonable request.
Author contributions. PRK collected samples, performed analysis, analysed the data and wrote the paper. MK helped PRK with sampling, data acquisition and interpretations. MM designed and supervised this work and approved the manuscript.

Competing interests. The authors declare that they have no conflict of interest.

Special issue statement. This article is part of the special issue "European Geosciences Union General Assembly 2018, EGU Division Energy, Resources \& Environment (ERE)". It is a result of the EGU General Assembly 2018, Vienna, Austria, 8-13 April 2018.

Acknowledgements. This research was funded by the Polish National Science Centre, scientific grant no. UMO2014/15/B/ST10/04171. The authors appreciate the cooperation of the incineration plant executives (who permitted the site visits and sampling), assistance of Juraj Majzlan and technical support of Stefan Kiefer during EDX data acquisition (Institut für Geowissenschaften, Friedrich-Schiller-Universität, Jena, Germany).

Edited by: Christopher Juhlin

Reviewed by: Christopher Juhlin and one anonymous referee

\section{References}

Allegrini, E., Maresca, A., Olsson, M. E., Holtze, M. S., Boldrin, A., and Astrup, T. F.: Quantification of the resource recovery potential of municipal solid waste incineration bottom ashes, Waste Manage., 34, 1627-1636, https://doi.org/10.1016/j.wasman.2014.05.003, 2014.

Chandler, A. J., Eighmy, T. T, Hartlén, J., Hjelmar, O., Kosson, D. S., Sawell, S. E., van der Sloot, H. A., and Vehlow, J.: Municipal solid waste incineration residues, Stud. Environ. Sci., 67, 174202, 339-418, 734-740, 1997.

Downs, R. T. and Hall-Wallace, M.: The American Mineralogist crystal structure database, Am. Mineral., 88, 247-250, 2003.

Environmental Protection Agency (EPA): European Waste Catalogue and Hazardous Waste List, Ireland, ISBN:1-84095-083-8, 2002.

Funari, V., Braga, R., Bokhari, S. N. H., Dinelli, E., and Meisel, T.: Solid residues from Italian municipal solid waste incinerators: A source for "critical" raw materials, Waste Manage., 45, 206-216, https://doi.org/10.1016/j.wasman.2014.11.005, 2015.

Kowalski, P. R., Kasina, M., and Michalik, M.: Metallic elements fractionation in municipal solid waste incineration residues, Energy Procedia, 97, 31-36, https://doi.org/10.1016/j.egypro.2016.10.013, 2016.

Kowalski, P. R., Kasina, M., and Michalik, M.: Metallic elements occurrences in the municipal waste incineration bottom ash, Energy Proced., 125, 56-62, https://doi.org/10.1016/j.egypro.2017.08.060, 2017.

Kuo, N. W., Ma, H. W., Yang, Y. M., Hsiao, T. Y., and Huang, C. M.: An investigation on the potential of metal recovery from the mu- 
nicipal waste incinerator In Taiwan, Waste Manage., 27, 16731679, https://doi.org/10.1016/j.wasman.2006.11.009, 2007.

Lam, C. H. K., Ip, A. W. M., Barford, J. P., and McKay, G.: Use of Incineration MSW Ash: A Review, Sustainability, 2, 1943-1968, https://doi.org/10.3390/su2071943, 2010.

Malczewski, J. and Nadulski, P.: Thermal treatment of wastes in ZUSOK - operational experience, VII Conference: "Dla Miasta i Środowiska - Problemy Unieszkodliwiania Odpadów”, Conference materials, 61-65, 2010 (in Polish).

Pikoń, K. and Grabski, T.: Incineration of hazardous waste - case study, Archiwum Gospodarki Odpadami i Ochrony Środowiska, 4, 57-68, 2006 (in Polish).

Rodella, N., Bosio, A., Dalipi, R., Zacco, A., Borgese, L., Depero, L. E., and Bontempi, E.: Waste silica sources as heavy metal stabilizers for municipal solid waste incineration fly ash, Arab. J. Chem., 10, 3676-3681, https://doi.org/10.1016/j.arabjc.2014.04.006, 2017.
Saffarzadeh, A., Shimaoka, T., Motomura, Y., and Watanabe, K.: Characterization study of heavy metal-bearing phases in MSW slag, J. Hazard. Mater., 164, 829-834, https://doi.org/10.1016/j.jhazmat.2008.08.093, 2009.

Wei, Y., Shimaoka, T., Saffarzadeh, A. and Takahashi, F. Mineralogical characterization of municipal solid waste incineration bottom ash with an emphasis on heavy metal-bearing phases, J. Hazard. Mater., 187, 534-543, https://doi.org/10.1016/j.hazmat.2011.01.070, 2011. 